\title{
Pengaruh Bahan Pakan (Solid dan Pelepah Sawit Fermentasi) terhadap Bobot Lahir Pedet Sapi Bali
}

\author{
E. Ramon ${ }^{1}$, Nurhaita ${ }^{2}$, W. A. Wulandari ${ }^{1}$, A. Ishak ${ }^{1}$, \& Z. Efendi ${ }^{1}$ \\ ${ }^{1}$ Balai Pengkajian Teknologi Pertanian BengkuluJln. Irian Km 6,5 PO.Box 1010 Bengkulu 38119 \\ ${ }^{2} J u r u s a n$ Peternakan. Fakultas Pertanian, Universitas Muhammadiyah Bengkulu \\ Email : rerramon@yahoo.com \\ (Diterima : 05 Juli 2020; Disetujui : 21 September 2020)
}

\begin{abstract}
The research was conducted in Sumber Arum Village, Seluma Regency from April to August 2018. The purpose of the study was to determine the effect of feed material (solid and fermented palm fronds) on female cows on the birth weight of calf Bali cattle. The material of the research was 7 months old pregnant cattles as many as 10 heads aged 2-4 years with initial Body Condition Score (BCS) of 3. Observations was conducted for 3 months with 1 month preliminary. The treatments used are: introductory treatment is forage 10\% (palm fronds and leaves $12.5 \mathrm{~kg} / \mathrm{head} /$ day, field grass $12.5 \mathrm{~kg} / \mathrm{head} /$ day) + fermented solid $2 \mathrm{~kg} / \mathrm{head} /$ day while the existing treatment is only given field grass as much as $10 \%$ of body weight + concentrate $2 \mathrm{~kg} / \mathrm{head} /$ day. Each treatment consisted of 5 animals as replicates. The results of the analysis with the $t$ test concluded that calf body weight at birth was not significantly different $(P>0.05)$ between treatments.
\end{abstract}

Keywords: Bali cattle, birth weight, fermented palm fronds, solid

\section{PENDAHULUAN}

Pemanfaatan hasil samping perkebunan sawit menjadi salah satu peluang besar untuk penyediaan pakan alternatif. Banyak penelitian telah dilakukan untuk memanfaatkan hasil samping industri sawit, salah satu by-product industriini yaitu bungkil sawit mempunyai nilai ekonomis yang tinggi namun ketersediaannya terbatas. Suatu saat bukan tidak mungkin hasil samping dari industri seperti tandan kosong, serat perasan, lumpur sawit/solid, pelepah dan daun sawit yang belum dimanfaatkan secara optimal akan menjadi sumber bahan pakan utama yang memiliki nilai ekonomis yang tinggi dan menjadi solusi untuk meningkatkan produktivitas sapi lokal secara nasional.

Peningkatan populasi dan pertambahan bobot badan dari usaha peternakan sapi potong terus diupayakan melalui pemanfaatan pakan berbasis limbah tanaman pertanian, namun penggunaan pakan lengkap masih perlu dipertimbangkan dalam memenuhi kebutuhan ternak (Utomo, 2004). Diversifikasi pemanfaatan produk samping (by-product) yang dianggap limbah (waste) pertanian dan perkebunan. Produk samping juga dapat mendorong perkembangan agribisnis ternak secara integratif dalam suatu sistem produksi terpadu, melalui daur ulang biomas yang ramah lingkungan atau dikenal "zero waste production system"(Wahyono et al., 2003). Petani saat ini telah terbiasa memanfaatkan sumber daya pertanian sebagai sumber pakan (Diwyanto, 2008). Potensi kelapa sawit saat ini sangat mendukung pengembangan populasi melalui program integrasi. Hal ini terjadi karena beberapa bagian dari tanaman kelapa sawit dapat dimanfaatkan sebagai pakan antara lain daun, pelepah, tandan kosong, serat perasan dan hasil samping proses pengolahan minyak sawit (solid dan bungkil inti sawit) sekitar 10 ton BK/ha (Matondang dan Rusdiana, 2013).

Pemberian pakan limbah perkebunan seperti solid, pelepah dan daun sawit dapat dikombinasikan dengan produk samping agroindustri seperti bungkil kelapa, dedak padi, limbah tebu, limbah industri pengolahan nanas, onggok dan bungkil kedelai dapat diberikan kepada ternak ruminansia. Provinsi Bengkulu saat ini mempunyai perkebunan kelapa sawit adalah 192.029 ha, dengan produksi 902.432 ton/tahun, produksi ratarata 6.725 ton/ha (BPS Provinsi Bengkulu, 2018). Luas perkebunan Kabupaten Seluma pada tahun 2017 adalah 10.267 ha Tanaman Belum Menghasilkan (TBM); Tanaman Menghasilkan (TM) 20.978 ha dan tanaman tidak menghasilkan/tanaman rusak adalah 183 ha dengan produksi 66.856 ton/tahun rata-rata 3.190 (BPS Kabupaten Seluma, 2018), saat ini produksi per hektar tanaman ini terus mengalami peningkatan, seiring dengan meningkatnya produksi maka hal ini menyebabkan hasil sampingan tanaman kelapa sawit ini akan terus menggunung di lahan 
berupa pelepah dan di pabrik pengolahan berupa solid. Wulandari dan Gunawan (2009) melaporkan pelepah dan daun kelapa sawit merupakan bahan pakan sumber serat kasar (SK), masing-masing memiliki kandungan SK $50,0 \%$ dan $21,5 \%$ sehingga dapat menggantikan atau mengurangi pemakaian rumput dalam pakan sapi potong.

Peningkatan populasi ternak, produktivitas ternak dan kualitas karkas atau daging perlu terus diusahakan hal ini seiring dengan berkembangnya penduduk yang diikuti dengan peningkatan kebutuhan akan protein hewani yang terus mengalami peningkatan. Salah satu tantangan dalam meningkatkan produktivitas ternak ruminansia adalah kurang tersedianya pakan yang berkualitas dengan harga kompetitif, tidak bersaing dengan mahluk hidup lain serta tersedia secara kontinyu. Produk samping perkebunan kelapa sawit adalah berupa pelepah, daun dan solid. Pemanfaatan hasil samping tanaman kelapa sawit (solid dan pelepah) diolah melalui silase memberikan pertambahan bobotbadan $\quad 0,52$ $\mathrm{kg} /$ hari/ekor pada sapi Bali (Ratna et al., 2017), dipertegas oleh Eni et al. (2017) pemanfaatan biomasa berupa pelepah sawit dan solid dari perkebunan sawit dapat memperbaiki kinerja dan reproduksi sapi.

Salah satu keunggulan ternak ruminansia adalah mampu memanfaatkan pakan berserat tinggi, seperti produk samping pertanian yang tidak bersaing dengan kebutuhan manusia, salah satu bahan pakan alternatif sumber serat pengganti rumput adalah hasil sampingan pertanian seperti solid dan pelepah kelapa sawit yang dapat dijadikan sebagai pakan tambahan dan pelepah kelapa sawit dapat menggantikan hijauan pakan. Panjaitan et al. (1998), menyimpulkan pemberian tambahan pakan pada akhir kebuntingan meningkatkan bobot lahir anak, mempertahankan skor kondisi tubuh induk, mempercepat waktu berahi kembali, memberikan pertambahan bobot badan anak yang lebih tinggi dan memberi tingkat keberhasilan IB yang lebih baik. Pemberian tambahan pakan pada akhir kebuntingan sangat dibutuhkan terutama induk dengan anak hasil persilangan yang memiliki bobot lahir yang lebih tinggi dan membutuhkan makanan yang lebih baik untuk pertumbuhan.

Bobot lahir merupakan faktor yang penting dalam pertumbuhan pedet sapi. Sapi dengan bobot lahir yang besar dan lahir secara normal akan lebih mampu mempertahankan kehidupannya (Prasojo et al., 2010). Pemberian ransum dengan kualitas baik pada saat induk bunting tua dapat berpengaruh terhadap peningkatan bobot lahir dan akan terjadi sebaliknya apabila kekurangan, bobot lahir pedet rendah, kondisi lemah dan tingkat kematian tinggi.

Untuk meningkatkan nutrien hasil sampingan perkebunan tanaman sawit berupa pelepah dan solid diperlukan beberapa metode diantaranya dengan proses biologi yaitu dengan fermentasi. Kadar lignin pada kulit pelepah dan daun sawit cukup tinggi yaitu sekitar 17,4\% dan 27,6\% (Jalaludin et al., 1991). Bobot kelahiran anak ditentukan oleh bangsa, induk, jenis kelamin anak, dan makanan induk saat kebuntingan (Sutan, 1988). Prasojo et al. (2010) melaporkan lama kebuntingan sapi Bali adalah 284 $\pm 5,7$ hari; dengan bobot lahir 18,4 $\pm 1,6 \mathrm{~kg}$. Cairussyuhur (2006) pada sapi Hissar Sumbawa lamanya kebuntingan tidak dipengaruhi jenis sapi dan jenis kelamin, namun yang memengaruhi lama kebuntingan adalah musim kelahiran. Tujuan dari penelitian ini adalah untuk mengetahui pengaruh bahan pakan (solid dan pelepah sawit fermentasi) terhadap bobot lahir pedet sapi Bali di Kabupaten Seluma.

\section{MATERI DAN METODE}

Penelitian dilaksanakan pada Kelompok Tani Tunas Harapan Desa Sumber Arum Kecamatan Sukaraja Kabupaten Seluma pada bulan April sampai dengan Agustus 2018. Materi penelitian adalah induk sapi bali betina bunting 7 bulan sejumlah 10 ekor yang berumur 2-4 tahun dengan skor kondisi badan (BCS) awal ternak 3. Penelitian dilakukan selama 4 bulan dengan 1 bulan prelim. Penelitian menggunakan uji t. Perlakuan introduksi adalah hijauan 10\% (pelepah dan daun sawit 12,5 kg/ekor/hari, rumput lapang $12,5 \mathrm{~kg} /$ ekor/hari) + solid fermentasi $2 \mathrm{~kg} /$ ekor/hari, sedangkan perlakuan eksisting diberikan rumput lapangan sebanyak $10 \%$ dari bobot badan + konsentrat $2 \mathrm{~kg} / \mathrm{ekor} /$ hari. Pengelompokan berdasarkan perlakuan yang diberikan. Kondisi bobot badan awal ternak untuk perlakuan eksisting rata-rata $226,9 \mathrm{~kg}$ dan perlakuan introduksi rata-rata $219,4 \mathrm{~kg}$, masing-masing perlakuan diulang 5 kali (sesuai jumlah ternak setiap perlakuan). Data yang di peroleh dianalisis menggunakan uji $\mathrm{t}$ (independent sample test) prosedur analisis menggunakan SPSS 17 (Sampurna dan Nindhia, 2008). 
Tabel 1. Komposisi bahan pakan yang di gunakan pada penelitian

\begin{tabular}{|c|c|c|}
\hline \multirow[t]{2}{*}{ Uraian } & \multicolumn{2}{|r|}{ Perlakuan } \\
\hline & Petani & Introduksi \\
\hline Pakan hijauan & Rumput lapangan & $\begin{array}{l}\text { Hijauan } 50 \% \text {, pelepah dan daun kelapa sawit } \\
\text { fermentasi } 50 \%\end{array}$ \\
\hline Pakan tambahan & Ampas tahu dan dedak & Solid fermentasi $2 \mathrm{~kg} /$ ekor/hari \\
\hline Vitamin & Diberikan & Diberikan \\
\hline Mineral & $0,01 \mathrm{~g} /$ ekor & $0,01 \mathrm{~g} /$ ekor \\
\hline Air minum & Adlibitum & Adlibitum \\
\hline
\end{tabular}

\section{Fermentasi Bahan Pakan Solid dan Pelepah Kelapa Sawit}

Teknologi fermentasi solid menggunakan aktivator $\mathrm{EM}_{4}$. Disiapkan lumpur sawit (solid), aktivator, tetes tebu dan urea. Dilarutkan bahan (aktivator, tetes tebu dan urea) menggunakan air. Dihamparkan solid dengan alas terpal, penyiraman hamparan solid dengan larutan bahan, solid diaduk sampai rata, campuran solid dan bahan dimasukkan ke dalam drum/ silo, menutup drum dengan rapat sampai kondisi an aerob, simpan selama 3 minggu (21 hari).

Pelepah dan daun kelapa sawit dirajang menggunakan mesin chopper hingga halus, kemudian dilarutkan urea dan aktivator dengan air secukupnya. Pelepah kelapa sawit yang sudah dirajang, dihamparkan pada terpal lalu disiram merata dengan larutan urea dan aktivator hingga larutan habis, kemudian diaduk hingga rata. Kemudian dimasukkan ke dalam drum, dipadatkan dan tutup rapat untuk mempertahankan kondisi tanpa udara (an erob) selama 1 minggu baru bisa digunakan. Pada saat bahan dibuka, dikeringanginkan terlebih dulu baru diberikan kepada ternak.

\section{HASIL DAN PEMBAHASAN}

\section{Bobot Lahir Pedet}

Bobot lahir pedet hasil penelitian dapat dilhat pada Tabel 2. Tabel 2 memperlihatkan bobot lahir pedet perlakuan eksisting adalah $13,9 \mathrm{~kg} /$ ekor dan perlakuan introduksi sebesar $14,6 \mathrm{~kg} /$ ekor. Hasil analisis dengan uji $\mathrm{t}$ diketahui bobot lahir pedet masing-masing perlakuan tidak berbeda nyata $(\mathrm{P}>0,05)$.

Tabel 2. Bobot lahir dan jenis kelamin

\begin{tabular}{ccccc}
\hline \multirow{2}{*}{ Ulangan } & \multicolumn{2}{c}{ Eksisting } & \multicolumn{2}{c}{ Introduksi } \\
\cline { 2 - 5 } & Bobot lahir $(\mathrm{kg})$ & Jenis Kelamin & Bobot lahir $(\mathrm{kg})$ & Jenis Kelamin \\
\hline U1 & 12,0 & Jantan & 14,0 & Betina \\
U2 & 16,0 & Betina & 16,0 & Jantan \\
U3 & 15,0 & Jantan & 14,0 & Betina \\
U4 & 13,5 & Jantan & 14,0 & Betina \\
U5 & 13,0 & Betina & 15,0 & Jantan \\
\hline Jumlah & 69,5 & & 73,0 & $14,6^{\text {ns }}$ \\
\hline Rata & 13,9 ns & & \\
\hline
\end{tabular}

Hal ini disebabkan oleh kemungkinan kandungan nutrisi pakan (Tabel 3) yang diberikan antara perlakukan introduksi dengan perlakuan eksisting tidak terlalu berbeda karena pada perlakuan eksisting selain memberikan hijauan berupa rumput lapangan, juga memberikan konsentrat berupa ampas tahu dan dedak. Hal ini sesuai dengan hasil penelitian Syawal et al. (2013), pakan merupakan faktor yang mempunyai pengaruh sangat penting terhadap laju pertumbuhan, apabila kualitasnya baik dan diberikan dalam jumlah cukup maka pertumbuhan ternak akan terjadi secara cepat demikian juga sebaliknya. Berdasarkan hasil penelitian yang dilakukan oleh Pasambe et al. (2000), menyimpulkan pemberian konsentrat pada induk sapi Bali maka akan memberikan penambahan pada bobot badan pedet pada saat melahirkan. 
Hasil penelitian ini menunjukkan pelepah dan daun kelapa sawit dapat digunakan sebagai pakan pengganti hijauan sebesar $50 \%$ (12,5 kg/ekor/hari) untuk memenuhi kebutuhan hijauan pakan induk sapi bunting terutama saat musim kemarau persediaan (hijauan sangat terbatas) (Mathius et al., 2004). Pelepah dan daun kelapa sawit segar dapat digunakan sebagai pakan ternak pengganti rumput sebanyak 30\% dalam ransum sapi potong, namun dapat ditingkatkan sampai $50 \%$ jika digunakan dalam bentuk silase (Wan Zahari et al., 2003) dan dalam bentuk pelepah sawit tanpa kulit dapat digunakan sampai 55\% (Azmi dan Gunawan, 2005).

Berdasarkan hasil analisis laboratorium kandungan nutrisi bahan pakan solid dan pelepah sawit yang difermentasi terjadi peningkatan protein, dan terjadi penurunan lemak, dibandingkan pakan yang tidak difermentasi. Peningkatan nutrisi disebabkan oleh proses fermentasi menggunakan aktivator $\mathrm{EM}_{4}$ (Tabel 3). Penelitian ini selaras dengan hasil penelitian yang dilakukan oleh Lie et al. (2015) fermentasi limbah sawit menggunakan Trichoderma reseei dosis $0,4 \%$ dengan lama fermentasi 1 minggu berhasil menurunkan serat kasar 33,52\% (turun dari 24,94\% menjadi $16,59 \%$ ) dan meningkatkan protein $22,24 \%$ (naik dari 6,04\% menjadi 7,38\%). Peningkatan komposisi nutrisi pakan seperti ini merupakan jenis pakan yang cukup baik untuk ternak sapi potong. Kandungan nutrisi bahan pakan yang digunakan pada penelitian ini terlihat pada Tabel 3 .

Tabel 3. Kandungan nutrisi bahan penelitian

\begin{tabular}{|c|c|c|c|c|c|c|}
\hline \multirow[t]{3}{*}{ Kandungan Nutrisi } & \multicolumn{4}{|c|}{ Bahan pakan } & \multirow{2}{*}{\multicolumn{2}{|c|}{$\begin{array}{c}\text { Pertambahan Nutrisi Setelah } \\
\text { Fermentasi }\end{array}$}} \\
\hline & \multicolumn{2}{|c|}{ Non Fermentasi * } & \multicolumn{2}{|c|}{ Fermentasi ** } & & \\
\hline & Solid & Pelepah & Solid & Pelepah & Solid & Pelepah \\
\hline Protein Kasar (\%) & 14,58 & 3,07 & 18,75 & 8,97 & 4,17 & 5,9 \\
\hline Lemak (\%) & 14,78 & 1,07 & 11,61 & 3,47 & $-3,17$ & 2,4 \\
\hline EM (KKal/g) & 4.841 & 4.082 & 4.054 & 4.424 & -787 & 342 \\
\hline SK (\%) & 35,88 & 50,94 & 21,42 & 38,62 & $-14,46$ & 12,32 \\
\hline Abu (\%) & 14,40 & 5,10 & 21,14 & 9,07 & 6,74 & 3,97 \\
\hline $\mathrm{Ca}(\%)$ & 1,08 & 0,96 & 1,68 & 0,29 & 0,6 & $-0,67$ \\
\hline $\mathrm{P}(\%)$ & 0,25 & 0,08 & 0,23 & 0,10 & $-0,02$ & 0,02 \\
\hline
\end{tabular}

Keterangan : ** Hasil Analisis proksimat Laboratorium Balitnak Ciawi Bogor 2018

* Sinurat et al. (2012).

Berdasarkan Tabel 3, diperoleh gambaran kandungan nutrisi dari limbah industri kelapa sawit yang belum difermentasi mengandung protein kasar 14,58\% masih rendah dibandingkan solid fermentasi yaitu $18,75 \%$ begitu juga halnya dengan protein kasar pelepah yang belum difermentasi hanya sebesar 3,07\% dan setelah difermentasi meningkat menjadi $8,97 \%$ dengan demikian pelepah dan solid fermentasi cukup baik digunakan sebagai pakan sapi bunting 7 bulan, sebagai pengganti hijauan. Peningkatan kandungan protein pelepah/daun kelapa sawit fermentasi sebesar 5,90\% menjadi 8,97\% hampir menyamai kandungan protein rumput unggul yang digunakan pada perlakukan eksisting, sehingga bobot kelahiran pedet tidak berbeda nyata. Hasil penelitian ini selaras dengan pendapat Sinurat et al. (2012), menyatakan pelepah dan daun kelapa sawit fermentasi dapat dipergunakan sebagai pengganti hijauan karena mempunyai kandungan nutrisi yang sama yaitu $8-14 \%$ protein yang hampir sama dengan rumput unggul.

Pada penelitian ini solid yang belum difermentasi mengandung protein kasar sebesar $14,58 \%$, setelah dilakukan fermentasi meningkat menjadi $18,75 \%$. Hasil penelitian ini lebih rendah dari yang dilaporkan Sinurat et al. (2005), proses fermentasi meningkatkan protein kasar dari $12,2 \%$ menjadi $24,5 \%$, kandungan energi metabolisme meningkat dari $1.593 \mathrm{Kkal} / \mathrm{kg}$ menjadi $1.717 \mathrm{Kkal} / \mathrm{kg}$. Melihat dari peningkatan kandungan protein ini hasil penelitian ini diharapkan dapat menjadi alternatif sumber protein bagi ternak. Pada penelitian ini kandungan lemak solid sebelum difermentasi adalah 14,78\%, setelah difermentasi turun 11,61\%. Kandungan lemak ini masih cukup tinggi sehingga sebaiknya dalam pemberian pada ternak sapi agar dicampurkan dengan bahan lainnya seperti kulit kopi, dedak padi. 
Jenis kelamin pedet pada perlakuan eksisting betina sebanyak 2 ekor pedet dan jantan sebanyak 3 ekor sedangkan pada perlakuan introduksi berjenis kelamin betina sebanyak 3 ekor pedet dan berjenis kelamin jantan sebanyak 2 ekor (Tabel 2). Hasil penelitian menunjukkan jenis pakan dan kandungan nutrisi pakan tidak memengaruhi jenis kelamin pada kelahiran pedet, tetapi jenis kelamin ternak sapi yang dikandung oleh ternak memengaruhi lamanya kebuntingan. Muslim et al. (2013) bahan dan nutrisi pakan tidak memengaruhi jenis kelamin ternak sapi. Ditambahkan oleh Prasojo et al. (2010) salah satu faktor yang memengaruhi jenis kelamin pedet pada saat kelahiran adalah lamanya kebuntingan.

\section{KESIMPULAN}

Pemberian bahan pakan berupa (solid dan pelepah sawit fermentasi) kepada ternak sapi memengaruhi bobot lahir pedet sapi.

\section{UCAPAN TERIMA KASIH}

Terimakasih penulis sampaikan kepala BPTP Bengkulu yang telah membantu memberikan saran dan pendapat dalam pelaksanaan kegiatan penelitian, kepada pengurus kelompok tani Tunas Harapan Desa Sumber Arum Kabupaten Seluma, yang telah menangani pemeliharaan ternak sapi pada keberlangsungan penelitian ini dan kepada semua pihak yang telah membantu selama penelitian ini.

\section{DAFTAR PUSTAKA}

Azmi \& Gunawan, 2005. Pemanfaatan pelepah kelapa sawit dan solid untuk pakan sapi potong. Dalam I. W. Mathius, S. Bahri, L. H. Prasetyo, E. Triwulaningsih, B. Tiesnamurti, I. Sendow, dan Suhardono. Penyunting. Inovasi Teknologi Peternakan untuk Meningkatkan Kesejahteraan Masyarakat dalam mewujudkan Kemandirian dan Ketahanan Nasional. Pros. Seminar Teknologi Peternakan dan Veteriner. Bogor, 12-13 September 2005. p.143- 146.

Badan Pusat Statistik (BPS) Provinsi Bengkulu. 2018. Bengkulu Dalam Angka. Bengkulu.

Cairussyuhur, A. 2006. Faktor-Faktor yang mempengaruhi lama kebuntingan pada sapi Hissar Sumbawa. Jurnal Ilmiah Ilmu-Ilmu Peternakan. 9(4):5-241.
Diwyanto, K. 2008. Pemanfaatan sumberdaya lokal dan inovasi teknologi dalam mendukung pengembangan sapi potong di Indonesia. Pengembangan Inovasi Pertanian. 1:173-188.

Eni, S. R., S. Nurawaliah, Supriyono, \& Anggraeni. 2017. Peran solid sebagai pakan tambahan terhadap kinerja produktivitas sapi dalam Sistem Integrasi Sawit-Sapi. Bunga Rampai. Akselerasi Pengembangan Sapi Potong Melalui Sistem Integrasi Tanaman Ternak Sawit-Sapi. ISBN 978-602-440-250-1. Penyunting: I. Wayan Mathius, Sjamsul Bahri dan Subandriyo. IPB. Press Halaman 145-163.

Jalaluddin, S., Z. A. Zelan, N. Abdullah, \& Y. H. Ho. 1991. Recent Developments in the Oil Palm ByProduct Based Ruminant Feeding System, MSAP, Penang, Malaysia pp: 35-44.

Lie, M., M. Najoan, \& F. R. Wolayan. 2015. Peningkatan nilai nutrien (protein kasar dan serat kasar) limbah solid kelapa sawit terfermentasi dengan Trichoderma reesei. Jurnal LPPM Bidang Sains dan Teknologi. 2(1):34-43.

Matondang, R. H., \& S. Rusdiana. 2013. Langkahlangkah Strategis dalam Mencapai Swasembada Daging sapi/kerbau). Puslitbangnak. Bogor. Indonesia.

Mathius, I. W., D. M. Sitompul, B. P. Manurung, \& Azmi. 2004. Produk samping tanaman dan pengolahan buah kelapa sawit sebagai bahan dasar pakan komplit untuk sapi : Suatu tinjauan. Prosiding Sistem integrasi Kelapa Sawit-Sapi. Balitbang Pertanian, Pemprov Bengkulu dan PT Agricinal. Bengkulu. Sept. 2003. pp. 120 - 128.

Muslim, K. N., H. Nugroho, \& T. Susilawati. 2013. Hubungan antara bobot badan induk dan bobot lahir pedet sapi Brahman cross pada jenis kelamin yang berbeda. Jurnal Ilmu-Ilmu Peternakan. 23(1):18-24.

Ratna, A. D., Harmaini, \& R. Wahyuni. 2017. Pemanfaatan produk samping industri sawit sebagai bahan pakan di Sumatra Barat. Bunga Rampai. Akselerasi Pengembangan Sapi Potong Melalui Sistem Integrasi Tanaman Ternak Sawit-Sapi. ISBN 978-602-440-250-1. Penyunting : I. Wayan Mathius, Sjamsul Bahri dan Subandriyo. IPB.Press. Halaman 81-98.

Sampurna, I. P., \& T. S. Nindhia. 2008. Analisis data dengan SPSS dalam Rancangan Percobaan Udayana University Press. Denpasar.

Sinurat, A. P., T. Purwadaria, I. W. Mathius, Tyasno, H. Hamid, \& B. P. Manurung. 2005. Pengembangan Teknologi Fermentasi Limbah Sawit (Ferlawit) untuk Pakan Ternak Skala Produksi Komersil. Laporan Hasil Penelitian. Kerja sama antara Balai Penelitian Ternak Ciawi dan P.T. Agricinal-Bengkulu.

Sinurat, A. P., I. W. Mathius, \& T. Purwadaria. 2012. Pengolahan dan Pemanfaatan Hasil Samping Industri Sawit sebagai Bahan Pakan. Badan 
Penelitian dan Pengembangan Pertanian. IAARD Press. Jakarta.

Sutan, S. M. 1988. Perbandingan performans reproduksi dan produksi antara Sapi Brahman, Peranakan Ongole, dan Bali di Daerah Transmigrasi Batu Marta Sumatra Selatan Disertasi. Institut Pertanian Bogor. Bogor.

Syawal, S., B. P. Purwanto, \& I. G. Permana. 2013. Studi hubungan respon ukuran tubuh dan pemberian pakan terhadap pertumbuhan sapi pedet dan dara pada lokasi yang berbeda. JITP. 2(3):175-188.

Utomo, R. 2004. Review hasil-hasil penelitian pakan sapi potong. Wartazoa. 14(3):116-124.

Panjaitan, T. S., W. Arief, A. Sauki, A. Muzani, I. Basuki, \& A. S. Wahid. 1998. Pengaruh pemberian tambahan pakan pada induk bunting dan setelah melahirkan terhadap pertumbuhan anak, berahi kembali dan keberhasilan IB pada usaha pertanian sapi potong di Pulau Lombok. Seminar Nasional Peternakan dan Veteriner. Hal. 272-278.

Pasambe, D., . M. S. Ubang, A. Nurhayu, S. Bahar, \& Chalidjah. 2000. Pengaruh perbaikan pakan pada induk Sapi Bali terhadap pertambahan bobot badan pedet yang sedang menyusui. Seminar Nasional Peternakan dan Veteriner. Halaman 224-227.
Prasojo, G, I. Arifiantini, \& K. Mohammad. 2010. Korelasi antara lama kebuntingan, bobot lahir dan jenis kelamin pedet hasil inseminasi buatan pada sapi Bali. J. Veteriner. 11(1):41-45.

Wahyono, D. E, R. Hardianto, C. Anam, D. B. Wijono, T. Purwanto, \& M. Malik. 2003. Strategi Pemanfaatan Limbah Pertanian dan Agroindustri Untuk Pembuatan Pakan Lengkap Ruminansia. Makalah Seminar Nasional Pengembangan Sapi Potong. Pusat Penelitian dan Pengembangan Peternakan. Badan Litbang Pertanian. Bogor.

Wan Zahari, M, O. B. Hassan, H. K. Wong, \& J. B. Liang. 2003.Utilization of oil palm frond-based diets for beef cattle production in Malaysia. Asian-Aust J. Anim Sci. 16:625-634.

Wulandari, W. A. \& Gunawan. 2009. Membangun Laboratorium Agribisnis Prima Tani Bengkulu melalui sistem integrasi. Dalam prosiding lokaraya nasional sistem integrasi tanamanternak. Semarang, 13-14 November 2007. Puslitbangnak 336-343. Bogor. 